\title{
THE IMPORTANCE OF FOREIGN DIRECT INVESTMENT FOR SOUTH EAST EUROPEAN COUNTRIES' AGRICULTURE
}

\author{
Sandra Stojadinović Jovanović ${ }^{1}$, Boban Dašićc
}

\begin{abstract}
Summary
As agriculture is strategically important sector for economic development and growth, it is also important every mode of foreign participation in agriculture, including foreign direct investments (FDI). The aim of the paper is to consider whether there are opportunities and potentials for improvements in SEE countries' agriculture through FDI and in which segments. Therefore, the paper analyses agricultural characteristics within other macroeconomic characteristics of SEE countries' economies and also possible FDI impacts on agriculture aiming to determine if there are opportunities for improvements in SEE agriculture through FDI. Research results, presented in the paper, suggest that FDI has significant potential for support and improvement of SEE countries' agricultural performances. However, there is a need for higher level of FDI in order to use potential positive effect as well as recognition of these potential benefits from FDI inflow in agriculture by the governments and policy makers.
\end{abstract}

Key words: foreign direct investments, SEE countries, agriculture.

JEL: $F 21, Q 10$

\section{Introduction}

As agriculture is essentially important for economic development and growth, any form of foreign participation in this sector of the country is very important. The different modes of foreign participation in agriculture may be summarized as the following:

- indirect, non-equity participation through implementation of standards and other information-intensive relationships in which a host country farmer/firm produces to the specifications of a foreign company involved in activities downstream or upstream of production in the host country;

- direct, non-equity participation through contract farming;

1 Sandra Stojadinović Jovanović, Ph.D., Assistant Professor, Faculty of Economics, University of Belgrade, Kamenicka Street no. 6, 11000 Belgrade, Serbia, Phone: + 381113021 036, E-mail: sandra@ekof.bg.ac.rs

2 Boban Dašić, Ph.D., Assistant Professor, Faculty of Trade and Banking, Alfa University, Palmira Toljatija Street no. 3, 11070 Belgrade, Serbia, Phone: + 381656265 211, E-mail: bobandasickg@gmail.com

EP 2015 (62) 3 (661-675) 
- direct equity participation through foreign direct investment (FDI), whereby coordination and control of transactions are fully internalized within the company (UNCTAD, 2009).

One of the most common forms of foreign participation in agriculture is direct equity participation through wholly-owned affiliates that is foreign direct investment (FDI).

There are different definitions of FDI by IMF (IMF, 1993), OECD (OECD, 1996), World Bank (WB, 2004) or UNCTAD (UNCTAD, 2004) and they are all mutually very consistent (detailed in: Jovović et al., 2014). FDI implies investment in an enterprise that includes ownership control over it. As a relevant criterion for the investor to influence or to participate in the management of the company, it is used the threshold of at least $10 \%$ of ownership capital. Investor realizes significant influence on the management of the company, retains full control of the invested capital and makes decision on the use of capital (decides where to invest capital, how to organize production, takes care of the business results etc.) and bears the entire risk of capital using (Stojadinović Jovanović, 2008).

South East European (SEE) countries appear in the prevailing role of host countries of FDI inflows (their FDI inflows significantly exceed FDI outflows), which inevitably raises the question of FDI impacts on these countries' economies, including their agriculture. SEE countries are usually analyzed as a part of a Central and Eastern European (CEE) countries' group. But this group of countries has its own characteristics, which stand out from the CEE countries' group and which have influenced our analysis to focus on five SEE countries: Albania, Bosnia and Herzegovina (B\&H), Macedonia, Montenegro and Serbia.

SEE economies are featured by luck of domestic resources and investments and, therefore, by huge need for foreign investments. This fact produces the importance of FDI for SEE economies. Whether FDI are important or might be important for their agriculture and how, the paper will show. The importance of FDI for SEE agriculture will be seen through the identification of areas and aspects of SEE agriculture where FDI might bring improvements.

In order to conduct our research and fulfil the aim of research, the research has been carried out in several parts. First, it explores the ambient in which the agriculture of SEE countries takes place by including indicators of macroeconomic performances of these countries, trying to find out whether there are similarities in their macroeconomic environment. Then, in the second part, the research focuses on the SEE agricultural characteristics revealing whether there are common characteristics of SEE countries' agriculture and any limitations and constrains that should be improved. Third part is devoted to the analyses of the level and volume of FDI in SEE agriculture. Rather it researches the share of agricultural FDI in global FDI, as well as in SEE countries' FDI, finding out the levels and tendencies in movement of their shares. Then, in the fourth part, the paper researches general FDI effects on agriculture, i.e. whether FDI can bring positive impacts and improvements in agriculture generally. Finally, given the state of SEE agriculture and its constrains, on one side, and potential impacts of FDI on agriculture, on the other side, the fifth part concludes the research through the main research result - the identification of those FDI impacts which may bring improvements in agriculture of SEE 
countries. The special significance of the paper is reflected precisely in the identification of potential positive impacts which SEE countries might get from FDI inflow, starting from the findings of their main unfavourable country agricultural features and agricultural constrains.

\section{Aim of the paper, materials and methods}

The aim of the paper is that, through synthesis of identified common macroeconomic characteristics of SEE countries' economies and their agriculture (especially it's constrains and unfavorable features), on the one side, and possible impacts of FDI in agriculture, on the other side, to identify potential areas and ways for improvement in SEE agriculture through FDI. Therefore, the paper analyses agricultural characteristics within other macroeconomic characteristics of SEE countries' economies and also the possible impact of FDI on agriculture, suggesting that there is potential for improvement in SEE countries' agriculture through FDI.

The data used in the research were obtained from three main sources. These are the UNCTAD database, EBRD database and World Development Indicators of the World Bank database. Also national and international literature and related theoretical and practical studies were used in order to get and confirm the results.

The paper is based on the hypothesis that while general improvements which FDI inflow may bring to host countries' economies by transfer of capital, technology, knowledge and other missing resources, there are also potentials for improvements in individual sectors of the country, including agriculture, through FDI.

The SEE countries appear in prevailing role of host countries, as their FDI inflows substantially exceeded their FDI outflows (based on data from UNCTAD database). These FDI inflows might bring many improvements and positive effects on their economics, such as effects of transfers of various resources (capital, technology, management), effects on the balance of payments, competition and economic growth, industrial structure and entrepreneurship, employment and trade (Stojadinović Jovanović, 2008).

Broad literature gives different opinions about the FDI impacts on host countries' economies in which significant number of studies underlines the positive effects. Caves (1974 and 1996) observes several positive effects of FDI such as productivity gains, transfer of technology, managerial skills and know-how and access to international production network and market. Rappaport (2000) observes that FDI improves productivity of both the firms that receives FDI and also all other host country firms due to technological spill-overs. Literature review of FDI impacts on host country economies is given by Wan (2010). Also there is broad literature concerning the FDI impacts on transition SEE or CEE economies. For example, Zemplinerová (1998) analyzes and compares the share of both foreign investment enterprises and domestic enterprises in total manufacturing output, allocation pattern, specialization and concentration; Hunya examines FDI impacts on competitiveness (Hunya, 2000) and on growth and restructuring in Central European transition countries (Hunya, 2002); while Kalotay (2010) examined the contribution of FDI to structural changes in different groups of transition countries. The identified positive effects of FDI stimulate countries to try to 
attract more FDI inflows, especially SEE economies which suffer from the luck of domestic investments and resources and, therefore, have the huge need for foreign investments.

Further elaboration of the initial hypothesis leads us to the opinion that if FDI might bring improvements in countries' economies, FDI might also bring improvements in agriculture. A number of studies show the importance of FDI for a country's agriculture. Some of them suggests that in order to boost agricultural output and develop the sector as a whole more FDI should be sourced (Izuchukwu et al., 2012), some suggests that FDI inflows improve the international overall competitiveness of agricultural processing ( $\mathrm{Li}, 2012)$, some shows that there is a positive relationship between agricultural growth and FDI in the short- and long-run (Ahmed et al., 2014), while some shows that there is long-term co-integration relationship between agricultural FDI and trade (Ping et al., 2009).

Furthermore, if SEE countries have common agricultural characteristics, within other macroeconomic characteristics, then FDI inflow might bring some common impacts on their agriculture. Therefore, the paper aims to identify these common features of SEE agricultural performances, including their limitations and constrains, in order to recognize the areas and aspects in which FDI might bring improvements. Also the paper's aim is to identify the types of improvements and in which segments they might be, concerning SEE countries' agricultural characteristics.

For the purposes of research, different methods have been used. For the first and second part of the research the comparative analysis of SEE countries and benchmarking of their macroeconomic and agricultural characteristics have been used. The third part of research applies analysis as a method of research of agricultural FDI volumes and shares in global and national FDI, trying to find out the tendencies in their movements. The fourth part implies deductive method going from general effects and impacts of FDI to their impacts on individual host country's agriculture. The fifth part of research is based on the synthesis method of research observations and induction method, going from individual SEE countries' agricultural constrains and FDI impacts to identification of general areas for SEE agricultural improvements through FDI.

\section{Research results and discussion}

The first part of research, regarding macroeconomic performances of SEE countries, shows that these countries have many similar macroeconomic performances that can be seen through indicators of macroeconomic environment (Table 1). The observed five SEE countries are similar in the level of GDP per capita and in the level of GDP growth and GDP per capita growth. Except Albania, all have negative rates of the two indicators: GDP growth and GDP per capita growth. Inflation generally is not a problem, while Serbia's rate stands out. The foremost problem for all is unemployment, particularly in Macedonia (31\%), but also in B\&H (28\%), Serbia (24\%) and Montenegro (20\%). Trade openness of SEE countries measured as total trade to GDP varies around value 1 (from 1.3 in Macedonia and 1.1 in Montenegro to 0.9 in Serbia and about 0.8 in Albania and B\&H), while exports to GDP ratio exceeds one-third for all SEE countries. The region countries 
are also characterized by higher values of import compared with export and considerable values of merchandise trade deficits (WTO, 2012). One more similarity is that all five observed SEE countries are in the EU accession process.

Table 1. Macroeconomic indicators of SEE countries

\begin{tabular}{|c|c|c|c|c|c|}
\hline Indicator & Albania & B\&H & Macedonia & Montenegro & Serbia \\
\hline Land area (sq. km) & 27,400 & 51,000 & 25,220 & 13,450 & 87,460 \\
\hline Population (000) & 3,162 & 3,834 & 2,106 & 621 & 7224 \\
\hline GDP (current US\$) millions & 12,648 & 17,466 & 9,612 & 4,373 & 37,489 \\
\hline GDP growth (annual \%) & 1.6 & -0.70 & -0.27 & -0.54 & -1.7 \\
\hline GDP per capita (current US\$) & $3,999.9$ & $4,555.6$ & $4,565.3$ & $7,041.2$ & $5,189.6$ \\
\hline GDP per capita growth (annual \%) & 1.34 & -0.56 & -0.35 & -0.61 & -1.22 \\
\hline Inflation, consumer prices (annual \%) & 2.03 & 2.05 & 3.32 & 3.18 & 7.33 \\
\hline Unemployment (\% of total labor force) & 14.09 & 28.1 & 31 & 19.6 & 23.9 \\
\hline Trade ( $\%$ of GDP) & 80.4 & 86.3 & 128.7 & 108.5 & 92.4 \\
\hline Exports of goods and services (\% of GDP) & 31.3 & 31.2 & 53.2 & 42.4 & 38.2 \\
\hline
\end{tabular}

Source: data from WB database.

Regarding the degree of the transition process completion, seen through transition indicators of $\mathrm{EBRD}^{3}$, SEE countries also show similar results (Table 2). The highest progress all SEE countries have in price liberalization and trade and foreign exchange system, reaching the indicators value of 4.0 or 4.3. The largest drop back for all is within governance and enterprise restructuring and competition policy with the indicators value of 2.0 or 2.3 (except 2.7 for Macedonia). In price liberalization SEE countries have reached the standard of market economies achieving the indicator value of 4.3 (Albania and Macedonia) and 4.0 (B\&H, Montenegro and Serbia), while in trade and foreign exchange system the three of them have achieved the standard of market economy (Albania, Macedonia, Montenegro) and the other two (B\&H and Serbia) are getting closer. In competition policy all SEE countries are away from the market economy with the smallest value of this indicator (2.3 for Albania, B\&H and Serbia, 2.0 for Montenegro and 2.7 for Macedonia).

Table 2. Transition indicators of SEE countries

\begin{tabular}{|l|c|c|c|c|c|c|c|c|c|c|}
\hline \multirow{2}{*}{\multicolumn{1}{|c|}{ Indicator }} & \multicolumn{2}{|c|}{ Albania } & \multicolumn{2}{c|}{ B\&H } & \multicolumn{2}{c|}{ Macedonia } & \multicolumn{2}{c|}{ Montenegro } & \multicolumn{2}{c|}{ Serbia } \\
\cline { 2 - 13 } & 1989 & 2012 & 1989 & 2012 & 1989 & 2012 & 1989 & 2012 & 1989 & 2012 \\
\hline Large scale privatization & 1,0 & 3,7 & 1,0 & 3,0 & 1,0 & 3,3 & 1,0 & 3,3 & 1,0 & 2,7 \\
\hline Small scale privatization & 1,0 & 4,0 & 3,0 & 3,0 & 3,0 & 4,0 & 3,0 & 3,7 & 3,0 & 3,7 \\
\hline $\begin{array}{l}\text { Governance and enterprise } \\
\text { restructuring }\end{array}$ & 1,0 & 2,3 & 1,0 & 2,0 & 1,0 & 2,7 & 1,0 & 2,3 & 1,0 & 2,3 \\
\hline Price liberalisation & 1,0 & 4,3 & 2,7 & 4,0 & 2,7 & 4,3 & 2,7 & 4,0 & 2,7 & 4,0 \\
\hline
\end{tabular}

3 European Bank for Reconstruction and Development (EBRD) assesses progress in transition through a set of six transition indicators: large scale privatisation, small scale privatisation, governance and enterprise restructuring, price liberalisation, trade and foreign exchange system and competition policy. EBRD assesses progress in transition through this set of indicators which are used to track reform developments in observed countries since 1989. Progress is measured against the standards of industrialised market economies. The indicator values can range from 1 to $4+$, where 1 represents little or no change from a rigid centrally-planed economy and $4+$ represents the standards of an industrialised market economy.

EP 2015 (62) 3 (661-675) 


\begin{tabular}{|l|c|c|c|c|c|c|c|c|c|c|}
\hline \multirow{2}{*}{ Indicator } & \multicolumn{2}{|c|}{ Albania } & \multicolumn{2}{c|}{ B\&H } & \multicolumn{2}{c|}{ Macedonia } & \multicolumn{2}{c|}{ Montenegro } & \multicolumn{2}{c|}{ Serbia } \\
\cline { 2 - 12 } & 1989 & 2012 & 1989 & 2012 & 1989 & 2012 & 1989 & 2012 & 1989 & 2012 \\
\hline Trade \& Forex system & 1,0 & 4,3 & 2,0 & 4,0 & 2,0 & 4,3 & 2,0 & 4,3 & 2,0 & 4,0 \\
\hline Competition policy & 1,0 & 2,3 & 1,0 & 2,3 & 1,0 & 2,7 & 1,0 & 2,0 & 1,0 & 2,3 \\
\hline
\end{tabular}

Source: data from EBRD database.

The processes that featured SEE economies in the last two decades such as transition, ownership transformation and restructuring have shaped their business environment and macroeconomic milieu and determined their attractiveness for foreign investors. The environment in which the goal was ownership transformation of state enterprises, while their privatization was being carried out under conditions which did not only allow this, but also stimulated the participation of foreign investors through investment incentives, in essence determined investment attractiveness of these countries. These are economies in which ownership transformation and privatization processes were the main channels of FDI inflows (Stojadinović Jovanović, 2013). FDI in SEE countries were featured by the trend of growth during the 2000s. The average level of FDI in these economies during 2000-2012 was from $\$ 310$ million (Macedonia) to $\$ 512$ million (Montenegro and B\&H), \$559 million (Albania) and $\$ 1,671$ million (Serbia); while the total sum of received FDI, in the same period, was from $\$ 4$ billion (Macedonia) to $\$ 6.6$ billion (Montenegro and B\&H), $\$ 7.3$ billion (Albania) and to $\$ 21.7$ billion (Serbia). The FDI inward stock in this period has also risen in all SEE countries (FDI data from UNCTAD database). The largest increase had Serbia (25 times), then Albania (20 times) and Macedonia (9 times). Serbia and Albania stand out regarding the average and the total sum of FDI inflows, as well as FDI stock increase (although the starting level of FDI stock in 2000 was very low).

In the second part of the research regarding agricultural performances of SEE, comparative analysis of SEE countries reveals many common agricultural features of these economies (Table 3). These economies are characterized by significant share of agricultural land in total land (38\%-58\%), similar share of arable land in total land (about 20\%, except in Serbia and Montenegro which stand out with the highest and the lowest shares of 37\% and 13\% respectively), similar value of arable land per person (0.2-0.3 hectares per person, except Serbia where is 0.5 ), similar share of agriculture in GDP (about 10\%, except Albania where is $22 \%$ ) and similar agricultural employment (about 20\%, while Albania and Montenegro stand out with the highest and the lowest share of $41 \%$ and $6 \%$ respectively). It is also observed that, besides well preserved and rich in biodiversity environment, there are many unfavorable features of SEE countries' agriculture (Table 3) which are:

- prevaling small average farm size;

- low productivity;

- low level of modernization;

- low level of investments caused by limited investment capacity and low interest for investments;

- low level of business activities; 
- poorly developed infrastructure;

- low income and lack of alternative income sources.

Table 3. Findings for observed agricultural performances of SEE countries

\begin{tabular}{|c|c|c|c|c|c|c|}
\hline $\begin{array}{c}\text { Agricultural } \\
\text { performances }\end{array}$ & Albania & B\&H & Macedonia & Montenegro & Serbia & $\begin{array}{c}\text { Findings for SEE } \\
\text { agriculture }\end{array}$ \\
\hline $\begin{array}{l}\text { Agricultural land (\% } \\
\text { of land area) }\end{array}$ & 44 & 42 & 50 & 38 & 58 & $\begin{array}{l}\text { - significant share of } \\
\text { agricultural land in total }\end{array}$ \\
\hline $\begin{array}{l}\text { Arable land (\% of } \\
\text { land area) }\end{array}$ & 23 & 20 & 16 & 13 & 37 & $\begin{array}{l}\text { land } \\
\text { - similar share of arable }\end{array}$ \\
\hline $\begin{array}{l}\text { Arable land (hectares } \\
\text { per person) }\end{array}$ & 0.2 & 0.3 & 0.2 & 0.3 & 0.5 & $\begin{array}{l}\text { land in total land }(\sim 20 \% \\
\text { Serbia and Montenegro }\end{array}$ \\
\hline $\begin{array}{l}\text { Agriculture, value } \\
\text { added ( } \% \text { of GDP) }\end{array}$ & 22 & 8 & 10 & 9 & 10 & $\begin{array}{l}\text { Stand out) } \\
\text { similar value of arable } \\
\text { land per person (Serbia }\end{array}$ \\
\hline $\begin{array}{l}\text { Employment in } \\
\text { agriculture (\% of } \\
\text { total employment) }\end{array}$ & 41 & 20 & 17 & 6 & 21 & $\begin{array}{l}\text { stands out) } \\
\cdot \text { similar share of } \\
\text { agriculture in GDP }\end{array}$ \\
\hline $\begin{array}{l}\text { Average farm size } \\
\text { (ha/farm) }\end{array}$ & $\begin{array}{c}1.2 \text { (over } 80 \% \\
\text { are less } \\
\text { than } 2 \text { ha) } \\
\end{array}$ & $\begin{array}{c}3.3 \\
(50 \% \text { are less } \\
\text { than } 2 \text { ha) } \\
\end{array}$ & $\begin{array}{c}1.7 \\
(90 \% \text { are less } \\
\text { than } 2 \text { ha) } \\
\end{array}$ & $\begin{array}{c}3.2 \\
\text { (over } 60 \% \text { are } \\
\text { less than } 2 \text { ha) }\end{array}$ & $\begin{array}{c}3.7 \\
\text { (over } 40 \% \text { are } \\
\text { less than } 2 \text { ha) }\end{array}$ & $\begin{array}{l}\text { (Albania stands out) } \\
\text { - similar share of } \\
\text { agricultural labour in total }\end{array}$ \\
\hline \begin{tabular}{|l|} 
Agriculture value \\
added per worker \\
(constant 2005 USD) \\
\end{tabular} & 3,630 & 28,183 & 11,133 & 6,083 & 4,100 & $\begin{array}{l}\text { labour ( } 20 \% \text {; Albania } \\
\text { and Montenegro stand }\end{array}$ \\
\hline Productivity & \begin{tabular}{|c|} 
low productivity; \\
underdeveloped \\
irrigation and \\
drainage systems; \\
dominance of \\
crop production; \\
the smallest value \\
of agriculture \\
value added per \\
worker \\
\end{tabular} & $\begin{array}{l}\text { low productivity; } \\
\text { dominance of } \\
\text { crop production }\end{array}$ & $\begin{array}{l}\text { low productivity; } \\
\text { dominance of } \\
\text { crop production; } \\
\text { the fairly low } \\
\text { level of irrigation } \\
\text { (although the } \\
\text { highest among } \\
\text { SEE) }\end{array}$ & $\begin{array}{c}\text { low productivity; } \\
\text { the third smallest } \\
\text { value (after Albania } \\
\text { and Serbia) of } \\
\text { agriculture value } \\
\text { added per worker }\end{array}$ & $\begin{array}{l}\text { low productivity; } \\
\text { dominance of crop } \\
\text { production; low } \\
\text { level of irrigation; } \\
\text { the second } \\
\text { smallest value } \\
\text { (after Albania) of } \\
\text { agriculture value } \\
\text { added per worker }\end{array}$ & $\begin{array}{l}\text { out) } \\
\text { - prevaling small average } \\
\text { farm size } \\
\text { - the productivity } \\
\text { indicator shows the worst } \\
\text { situation in Albania, then } \\
\text { in Serbia; B\&H has the } \\
\text { most notable growth } \\
\text { - low productivity }\end{array}$ \\
\hline $\begin{array}{l}\text { Moderniza } \\
\text { tion }\end{array}$ & \begin{tabular}{|c|} 
low level of \\
modernization \\
of agricultural \\
holdings and \\
processing \\
industry \\
\end{tabular} & $\begin{array}{c}\text { low level of } \\
\text { modernization } \\
\text { of agricultural } \\
\text { holdings }\end{array}$ & $\begin{array}{c}\text { low level of } \\
\text { modernization } \\
\text { of agricultural } \\
\text { holdings }\end{array}$ & $\begin{array}{c}\text { low level of } \\
\text { modernization } \\
\text { of agricultural } \\
\text { holdings }\end{array}$ & $\begin{array}{c}\text { low level of } \\
\text { modernization } \\
\text { of agricultural } \\
\text { holdings }\end{array}$ & $\begin{array}{l}\text { strenghtened by the } \\
\text { dominance of crops } \\
\text { prodution in the majority } \\
\text { of the countries and the } \\
\text { low share of irrigated land }\end{array}$ \\
\hline $\begin{array}{l}\text { Interest for } \\
\text { investments } \\
\text { and investment } \\
\text { capacity }\end{array}$ & $\begin{array}{l}\text { low interest for } \\
\text { investments in } \\
\text { agriculture }\end{array}$ & $\begin{array}{c}\text { limited investment } \\
\text { capacity }\end{array}$ & $\begin{array}{c}\text { limited investment } \\
\text { capacity }\end{array}$ & $\begin{array}{c}\text { limited investment } \\
\text { capacity }\end{array}$ & $\begin{array}{l}\text { limited investment } \\
\text { capacity }\end{array}$ & $\begin{array}{l}\cdot \text { low level of } \\
\text { modernization }\end{array}$ \\
\hline Business activities & $\begin{array}{c}\text { poor marketing of } \\
\text { products }\end{array}$ & $\begin{array}{c}\text { low level of } \\
\text { business activity } \\
\text { in rural areas }\end{array}$ & \begin{tabular}{|c|} 
low level of \\
business activity \\
in rural areas \\
\end{tabular} & $\begin{array}{c}\text { low level of } \\
\text { business activity in } \\
\text { rural areas }\end{array}$ & $\begin{array}{c}\text { low level of } \\
\text { business activity in } \\
\text { rural areas }\end{array}$ & $\begin{array}{l}\text { - limited investment } \\
\text { capacity }\end{array}$ \\
\hline Environment & $\begin{array}{l}\text { well preserved } \\
\text { and rich in } \\
\text { biodiversity }\end{array}$ & $\begin{array}{l}\text { well preserved } \\
\text { and rich in } \\
\text { biodiversity }\end{array}$ & $\begin{array}{l}\text { well preserved } \\
\text { and rich in } \\
\text { biodiversity; } \\
\text { soil and water } \\
\text { sensitivity to } \\
\text { erosion in some } \\
\text { areas }\end{array}$ & $\begin{array}{c}\text { well preserved and } \\
\text { rich in biodiversi } \\
\text { ty; natural spring } \\
\text { water }\end{array}$ & $\begin{array}{l}\text { well preserved and } \\
\text { rich in biodiversity }\end{array}$ & $\begin{array}{l}\text { - low level of business } \\
\text { activities }\end{array}$ \\
\hline Rural areas & $\begin{array}{c}\text { poorly developed } \\
\text { infrastructure }\end{array}$ & $\begin{array}{c}\text { poorly developed } \\
\text { infrastructure; } \\
\text { rich natural and } \\
\text { cultural heritage }\end{array}$ & $\begin{array}{l}\text { poorly developed } \\
\text { infrastructure; } \\
\text { rich natural and } \\
\text { cultural heritage; } \\
\text { multifunctional } \\
\text { role of rural areas } \\
\end{array}$ & $\begin{array}{c}\text { poorly developed } \\
\text { infrastructure; } \\
\text { multifunctional role } \\
\text { of rural areas }\end{array}$ & $\begin{array}{l}\text { poorly developed } \\
\text { infrastructure; } \\
\text { rich natural and } \\
\text { cultural heritage, } \\
\text { multifunctional } \\
\text { role of rural areas } \\
\end{array}$ & $\begin{array}{l}\text { - well preserved and rich } \\
\text { in biodiversity } \\
\text { • poorly developed } \\
\text { infrastructure }\end{array}$ \\
\hline $\begin{array}{l}\text { Income and } \\
\text { income sources }\end{array}$ & $\begin{array}{c}\text { low income and } \\
\text { lack of alternative } \\
\text { income sources }\end{array}$ & $\begin{array}{c}\text { low income and } \\
\text { lack of alternative } \\
\text { income sources }\end{array}$ & $\begin{array}{l}\text { low income and } \\
\text { lack of alternative } \\
\text { income sources }\end{array}$ & $\begin{array}{l}\text { low income and } \\
\text { lack of alternative } \\
\text { income sources }\end{array}$ & $\begin{array}{l}\text { low income and } \\
\text { lack of alternative } \\
\text { income sources }\end{array}$ & $\begin{array}{l}\text { - low income and lack } \\
\text { of alternative income } \\
\text { sources }\end{array}$ \\
\hline
\end{tabular}

Source: Author's findings based on World Bank data; Mizik, 2012; Vujičić et al., 2012; Volk, 2010. 
The third part of research reveals the small share of agricultural FDI in global FDI as well as in SEE countries' FDI and the decreasing trend of global and SEE countries' FDI in agriculture. Over the past decades, the tendency of relative declining investments in agriculture has been observed, although the absolute level of investment has been increasing. The global world economy has been characterized by structural changes, including increased share of manufacturing and services (especially services) in FDI and decreased share of agriculture. The partial explanation of declining agricultural share lies in agricultural neglect and underinvestment in it, in favour of other two sectors. Long-term trend of declining agricultural prices contributed to this, too.

Between 1989 and 1991, world FDI flows in agriculture were below \$1 billion per year. In the period 2005-2007 they exceeded the value of $\$ 3$ billion per year, while in the following periods (2007-2009, 2008-2010 and 2009-2011) their absolute amounts became double exceeding \$6 billion (UNCTAD database). However, in spite of this tendency of absolute FDI growth in agriculture, they still make less than $1 \%$ of total world FDI inflows. Regarding the stock of FDI in agriculture, it is also observed very small and decreasing share in world inward FDI stock: from $0.4 \%$ in 1990 to $0.3 \%$ in 2009 and 2010 to $0.28 \%$ in 2011 (authors' calculations based on UNCTAD database; also in: Jovović et al., 2014). Therefore, these observations lead to the conclusion of insufficient agricultural attraction for foreign investments at the global level, as well as its declining importance.

At the level of individual countries, it is observed that share of agriculture in total FDI inflows, during the first decade of $21^{\text {st }}$ century, was moving at the level of less than $1 \%$ to $15 \%$. Furthermore the share of agriculture in total FDI stock is less than $1 \%$ in 21 countries of 40 developing countries observed ${ }^{4}$. Regarding SEE countries, the share of agriculture in total country's FDI inflows is also less than $1 \%$, except in Macedonia where is slightly above $1 \%$. The same situation is with FDI stock, where the share of agriculture in total FDI stock of these countries is also less than $1 \%$, except in Macedonia where is slightly above $1 \%$ (data from UNCTAD database). The highest absolute value of FDI inflows in agriculture, among SEE countries, has Serbia (together with the highest total and agricultural area and highest population - Table 1 and Table 3), followed by Macedonia. There is also observed tendency of declining shares of agriculture in FDI inflows and FDI stock of SEE countries. This means that similar to the tendency on the global level, there is insufficient attraction of this sector at the level of individual countries, including SEE countries, and its declining importance.

The fourth part of research is devoted to the general effects that FDI might have on agriculture, revealing whether FDI can bring positive impacts and improvements in agriculture in general. Foreign direct investors may be directly involved in agricultural

4 The observed countries are: Cambodia, Lao People's Democratic Republic, Malaysia, Ecuador, United Republic of Tanzania, Mozambique, Peru, Honduras, Indonesia, Ukraine, Ethiopia, Viet Nam, Vanuatu, Fiji, Chile, Costa Rica, Madagascar, Brazil, Islamic Republic of Iran, The FYR of Macedonia, Russian Federation, Jordan, China, Greece, Latvia, Estonia, Nicaragua, Romania, Lithuania, Republic of Moldova, Bulgaria, Poland, Serbia, Tunisia, Albania, Czech Republic, Mauritius, Mongolia, Egypt and Bangladesh. 
production, establishing wholly-owned affiliate, but they also may be purchaser of agricultural products or suppliers of inputs to agriculture or distributors of agricultural products, or they may be involved in activities such as processing, merchandising or marketing. FDI participation in agriculture includes also the other related activities and companies such as manufacturers and food processors, retailers, wholesalers and suppliers of different kind of inputs (equipment, fertilizers and seeds). According to the different modes of foreign participation in agriculture, there are different impacts on the country's agriculture. Possible positive impacts of FDI on agriculture can be seen through the whole agribusiness value chains, and they can be summarized as shown in Table 4.

Table 4 . Possible positive FDI impacts on host country's agriculture

\begin{tabular}{|c|c|c|c|c|}
\hline $\begin{array}{l}\text { Area od } \\
\text { impact }\end{array}$ & $\begin{array}{l}\text { Provision of inputs } \\
\text { and supplying them to } \\
\text { farmers }\end{array}$ & $\begin{array}{l}\text { Agriculture production and } \\
\text { operating plantations }\end{array}$ & $\begin{array}{l}\text { Procuring farm } \\
\text { produce and } \\
\text { processing }\end{array}$ & $\begin{array}{c}\text { Procuring } \\
\text { processed } \\
\text { products and } \\
\text { distributing } \\
\end{array}$ \\
\hline $\begin{array}{l}\text { Channels of } \\
\text { impact }\end{array}$ & $\begin{array}{l}\text { - Providing inputs } \\
\text { (seeds, agrochemicals, } \\
\text { machinery) to farmers } \\
\text { - Conducting R\&D }\end{array}$ & $\begin{array}{l}\text { - Undertaking investment in } \\
\text { agriculture production and } \\
\text { operating plantations }\end{array}$ & \multicolumn{2}{|c|}{$\begin{array}{c}\text { - Introducing and implementing } \\
\text { standards and coordinating the value } \\
\text { chain } \\
\text { - Selling in domestic markets and/or } \\
\text { exporting in foreign markets }\end{array}$} \\
\hline $\begin{array}{l}\text { Impacts on } \\
\text { agriculture }\end{array}$ & $\begin{array}{l}\bullet \text { Transferring } \\
\text { technology through } \\
\text { provision of inputs } \\
\text { • Influencing the } \\
\text { agricultural innovation } \\
\text { system }\end{array}$ & $\begin{array}{l}\text { - Increasing investment and } \\
\text { providing finance to farmers } \\
\text { - Transferring technology by } \\
\text { introducing new inputs and } \\
\text { methods; and undertaking R\&D } \\
\text { - Influencing the quantity and } \\
\text { quality of rural employment } \\
\text { - Linkages within and beyond } \\
\text { the agribusiness value chain, and } \\
\text { various effects on the economy at } \\
\text { large }\end{array}$ & \multicolumn{2}{|c|}{$\begin{array}{l}\text { - Promoting the commercialization } \\
\text { and modernization of agriculture } \\
\text { - Involving some farmers in the } \\
\text { value chain and providing assistance } \\
\text { to them } \\
\text { - Enhancing access to foreign } \\
\text { markets and promoting exports } \\
\text { - Competitive effects at various } \\
\text { stages in the value chain }\end{array}$} \\
\hline
\end{tabular}

Source: Authors' development based on UNCTAD, 2009.

Given the state of SEE agriculture and observed unfavourable features (Table 3), the importance of foreign direct investments in agriculture and the possible positive effects that FDI might bring comes to the fore for SEE countries (Table 4).

In the fifth part of research, synthesis of findings of the main common agricultural features and constrains of SEE countries, on the one side (Table 3), and possible positive impacts of FDI on country's agriculture, on the other side (Table 4), have resulted in the main research result - in the identification of potential areas and ways for SEE agricultural improvements through FDI (Table 5). 
Table 5. Identification of potential areas and ways for improvements in SEE agriculture through FDI

\begin{tabular}{|c|c|}
\hline $\begin{array}{l}\text { State of SEE agriculture: identified } \\
\text { agricultural constraints } \\
\text {-segment that needs improvement- } \\
\text { (Findings from Table 3) } \\
\end{array}$ & Potentials for agricultural improvements through FDI \\
\hline prevaling small average farm size & $\begin{array}{l}\text { - FDI, by purchasing and merging of small farms, may lead to } \\
\text { agglomeration }\end{array}$ \\
\hline low productivity & $\begin{array}{l}\text { - FDI may increase productivity through transfer of technology by } \\
\text { introducing new inputs and methods and conducting R\&D } \\
\text { - FDI may influence the quantity and quality of rural employment } \\
\text { - FDI may bring competitive effects at various stages in the value chain }\end{array}$ \\
\hline low level of modernization & $\begin{array}{l}\text { - FDI can intensify the commercialization and modernization of } \\
\text { agriculture } \\
\text { - FDI may lead to diffusion of international standards respecting } \\
\text { quality and safety of agricultural products } \\
\text { - FDI may influence and upgrade the agricultural innovation system }\end{array}$ \\
\hline low level of investment & $\begin{array}{l}\text { - FDI can contribute to total capital inflows to agriculture } \\
\text { - FDI can increase investment and provide finance to farmers }\end{array}$ \\
\hline low level of business activities & $\begin{array}{l}\text { FDI may increase and upgrade business activities through: } \\
\text { - Involving farmers in the value chain and providing assistance to them } \\
\text { - Linkages within and beyond the agribusiness value chain: linkages } \\
\text { with suppliers (backward linkages), linkages with customers (forward } \\
\text { linkages) and with others that are not part of agribusiness value chain, } \\
\text { producing various effects on the business activities and economy at } \\
\text { large } \\
\text { - Enhancing access to foreign markets and promoting exports }\end{array}$ \\
\hline poorly developed infrastructure & $\begin{array}{l}\text { - Investment in infrastructure facilities (transport infrastructure, water } \\
\text { supply, electrification etc.) to support FDI agricultural projects can } \\
\text { benefit farmers in connected locations and promote rural development } \\
\text { in general }\end{array}$ \\
\hline $\begin{array}{l}\text { low income and lack of alternative income } \\
\text { sources }\end{array}$ & $\begin{array}{l}\text { - FDI can increase the income of domestic farmers: those who are } \\
\text { directly employed by foreign-invested plantations or those who are } \\
\text { involved in different business schemes operated by foreign affiliates }\end{array}$ \\
\hline
\end{tabular}

Source: According to authors opinion based on in paper listed references.

The final research result shows that there are potentials for agricultural improvements through FDI (Table 5) and they are following:

- the identified SEE agricultural constrain regarding prevaling small average farm size can be removed or reduced through FDI, as activities of foreign investors, by purchasing and merging of small farms, may lead to agglomeration;

- the identified low productivity in SEE agriculture can be increased by transfer of technology through FDI, research and development (R\&D) conduction and introduction of new inputs and production methods, as well as by raising the quantity and quality of rural employment and also by increasing competitiveness at various stages in the value chain;

- the identified low level of modernization can be increased through commercialization and modernization of agriculture by FDI, which may lead to diffusion of international standards respecting quality and safety of agricultural products and an upgrade of the 
agricultural innovation system;

- the identified low level of investment can be increased through FDI because FDI presents inflow of capital in the country and contributes to the total capital inflows to agriculture and also FDI can increase investments and provide finance to farmers;

- the identified low level of business activities can be increased and upgraded by FDI by involving farmers in the value chain and providing assistance to them or through backward (linkages with suppliers) and forward linkages (linkages with customers) within and beyond the agribusiness value chain or through enhancing access to foreign markets and promoting exports;

- the identified undeveloped infrastructure can be improved by investments in infrastructure facilities (transport infrastructure, water supply, electrification etc.), which would also bring benefits to farmers in connected locations and promote rural development in general;

- the identified constrain of low income and lack of income sources can be reduced or removed by FDI as FDI can increase the income of domestic farmers: those who are directly employed by foreign-invested plantations or those who are involved in different business schemes operated by foreign affiliates.

\section{Conclusion}

The research, divided into several stages, has resulted in a number of findings. Researching the ambient in which the agriculture of selected five SEE countries takes place, by including indicators of macroeconomic performances of these countries, it has been observed that there are similarities in their macroeconomic environment. These similarities have been found in many macroeconomic indicators: in the level of GDP per capita, rates of GDP growth and GDP per capita growth, level of inflation, unemployment, trade openness and exports to GDP ratio, existence of merchandise trade deficits as well as the EU accession process. Also the similarities among these countries exist in the completion of the transition process, where SEE countries show many similar results. The highest progress all SEE countries have shown in price liberalization and trade and foreign exchange system, while the largest drop back all SEE countries have shown in governance and enterprise restructuring and competition policy. The privatization process was the main channel of FDI inflows into these countries which were featured by the trend of FDI growth during the 2000s'.

Researching the SEE agricultural characteristics, it has been observed that there are common characteristics of SEE countries' agriculture and especially common limitations and constrains that should be improved. The economies of these countries are featured by similar share of agricultural land in total land, share of arable land in total land, value of arable land per person, share of agriculture in GDP and agriculture employment and also by well preserved and rich in biodiversity environment. Further, many unfavourable features of SEE countries' agriculture have been detected, such as: prevaling small average farm size, low productivity, low level of modernization, low level of investments caused by limited 
investment capacity and low interest for investments, low level of business activities, poorly developed infrastructure, low income and lack of alternative income sources.

Researching the level and volume of FDI in SEE agriculture, more precisely the share of agricultural FDI in global FDI and in SEE countries' FDI, the small share of agricultural FDI and the decreasing trend of global and SEE countries' FDI in agriculture have been observed. The past decades were featured by the tendency of relative declining investments in agriculture, although the absolute level of investments has been increasing. This reflects the insufficient attraction of agriculture for foreign investments at the global level, as well as its declining importance. The same tendency has been noticed on the level of SEE countries - insufficient attraction of this sector and its declining importance.

Researching the general effects that FDI might have on agriculture, it has been revealed that FDI can bring positive impacts and improvements in agriculture generally. These impacts can be found through all fazes (provision, production and procurement), involving the whole agribusiness value chain, and can be realized through various channels of impact.

Performing synthesis of the conducted research, comprehending the findings of the main common agricultural features and constrains of SEE countries, on one side, and possible positive impacts of FDI on agriculture, on the other, the research has shown that there are potentials for agricultural improvements of SEE countries through FDI. It has identified the areas and segments that need improvements and the potential ways to realize these improvements through FDI.

Therefore, the research conducted in the paper has confirmed the initial hypothesis stating that based on general improvements which FDI may bring in host countries' economies, the improvements which FDI may bring in agriculture can also be found. The paper has identified the specific areas and segments where these improvements may be realized through FDI. Accordingly the importance of FDI for SEE countries' agriculture arises precisely from the identified positive impacts that FDI inflow might bring in agriculture of these countries.

The research has also shown the low level of FDI in SEE agriculture, indicating that potentials which might come from FDI are not being used. Therefore, there is a need for a higher level of FDI in the sector in order to get capacity and possibility to use potential positive effects. The research has also suggested the direction in which FDI inflows in SEE should be directed, aiming to realize some of these positive impacts.

Furthermore the identification of potential areas and ways for significant agricultural improvements through FDI is not enough by itself. It is necessary to recognize these potential benefits from FDI inflow in agriculture by the governments and policy makers. This recognition is very important through national policy of FDI and through giving the impetus for FDI in agriculture and their adequate guidelines. 


\section{Literature}

1. Ahmed, A., Al Amin, A. Q., Devadason, E. S., Mubarik, M. S. (2014): Does Inward Foreign Direct Investment Affect Agriculture Growth? Some Empirical Evidence from Pakistan, SSRN Electronic Journal no. 01, (available at: http://papers.ssrn.com/sol3/ papers.cfm?abstract id=2428577).

2. Caves, R. (1974): Multinational Firms, Competition and Productivity in the Host Country, Economica, no. 41, pp. 176-193.

3. Caves, R. (1996): Multinational Enterprise and Economic Analysis, Cambridge, England, Cambridge University Press.

4. EBRD database, Transition indicators by country, (available at: www.ebrd.com/ what-we-do/economic-research-and-data/data/forecasts-macro-data-transitionindicators.html).

5. Hunya, G. (2000): International Competitiveness Impacts of FDI in CEECs, Vienna Institute for International Economic Studies: Research Reports 268, Vienna, Austria.

6. Hunya, G. (2002): Recent Impacts of Foreign Direct Investment on Growth and Restructuring in Central European Transition Countries, Vienna Institute for International Economic Studies: Research Reports 284, Vienna, Austria.

7. IMF (1993): Balance of Payments Mannual, The $5^{\text {th }}$ edition, IMF, (available at: https:// www.imf.org/external/pubs/ft/bopman/bopman.pdf).

8. Izuchukwu, O. O., Huang, H., Shehu, A., Olufemi, E. A. (2012): FDI Trade and its Effects on Agricultural Development in Nigeria: Evidence from Time Series Analysis, The International Journal of Management Science and Business Administration, pp. 1-10, (available at: http://researchleap.com/wp-content/uploads/2014/11/Evidencefrom-time-series-analysis.pdf).

9. Jovović, D., Stojadinović Jovanović, S., Dašić, B. (2014): Agricultural Trade and Financing through FDI, Economics of Agriculture, Vol. 61, no. 2, pp. 455-469.

10. Kalotay, K. (2010): Patterns of Inward FDI in Economies in Transition, Eastern Journal of European Studies, vol. 1, pp. 55-76.

11.Li, S. (2012): An Empirical Analysis of the Impact of FDI on Agro-industries' Competitiveness - Based on the Perspectives of the Diamond Model and National Industry, Industrial Economic Review, no. 2, available at: http://en.cnki.com.cn/Article en/CJFDTOTAL-TQYG201202003.htm).

12. Mizik, T. (2012): A snapshot of Western Balkan's agriculture from the perspective of $E U$ accession, Studies in Agricultural Economics, no. 114, pp. 39-48.

13. OECD (1996): OECD's Benchmark Definition of Foreign Direct Investment, $3^{\text {rd }}$ edition, OECD, (available at: $h$ http://www.oecd.org/investment/investment-policy/2090148.pdf

14.Ping, F., Li Qing, X. (2009): Dynamic Relationship between Agricultural Trade and FDI in China, Asian Agricultural Research, vol. 1, no. 4, pp. 27-31, (available at: http:// ageconsearch.umn.edu/handle/53528). 
15. Rappaport, J. (2000): How Does Openness to Capital Flows Affect Growth?, Research Working Paper, RWP 00-11, Federal Reserve Bank of Kansas City, USA, December.

16. Stojadinović Jovanović, S. (2008): Transnacionalizacija međunarodne trgovine, Prometej, Beograd.

17. Stojadinović Jovanović, S. (2013): Svojinska transformacija i investiciona konkurentnost Srbije, in: Janićijević, N., Lovreta, S. (Eds.): Konkurentnost preduzeća u Srbiji, CID, Ekonomski fakultet, Beograd, pp. 425-448.

18. Volk, T., (2010): Agriculture in the Western Balkan Countries, Leibniz Institute of Agricultural Development in Central and Eastern Europe, IAMO, Vol. 57.

19. Vujičić, M., Ristić, L., Vujičić, M. (2012): European Integration and Rural Development Policy of the Republic of Serbia and West Balkan Countries, Bulgarian Journal of Agricultural Science, vol. 18, no, 4, pp. 519-530, Bulgaria.

20. UNCTAD (2004): World Investment Report 2004, UN, New York and Geneva, (available at: http://unctad.org/en/Docs/wir2004 en.pdf).

21. UNCTAD (2009): World Investment Report 2009, UN, New York and Geneva, (available at: http://unctad.org/en/docs/wir2009 en.pdf).

22. Wan, X. (2010): A Literature Review on the Relationship between Foreign Direct Investment and Economic Growth, International Business Research, vol. 3, no. 1, pp. $52-56$.

23. World Bank (WB) database, World Bank Indicators, (available at: http://databank. worldbank.org/data/views/reports/tableview.aspx\#).

24. World Bank (WB), (2004): World Development Indicators 2004, The International Bank for Reconstruction and Development/The World Bank, Washington, USA, p. 329.

25. WTO (2012): International Trade Statistics 2012, WTO, Geneva, Switzerland, (available at: www.wto.org/english/res e/statis e/its2012 e/its12 world trade dev e.pdf).

26.Zemplinerová, A. (1998): Impact of Foreign Direct Investment on the Restructuring and Growth in Manufacturing, Prague Economic Papers, no. 4, pp. 341-357, University of Economics, Prague. 


\title{
ZNAČAJ STRANIH DIREKTNIH INVESTICIJA ZA POLJOPRIVREDU ZEMALJA JUGOISTOČNE EVROPE
}

\author{
Sandra Stojadinović Jovanovič ${ }^{5}$, Boban Dašičc
}

\begin{abstract}
Rezime
Kako je poljoprivreda strateški značajan sektor za privredni razvoj i rast, to je i svaki oblik stranog učešća u poljoprivredi, uključujući strane direktne investicije (SDI), značajan. Cilj radajeste da razmotri da li postoje mogućnosti i potencijaliza poboljšanja upoljoprivredi zemalja JIE putem SDI i u kojim segmentima. Stoga rad analizira poljoprivredne u okviru drugih makroekonomskih karakteristika privreda zemalja JIE kao i moguće uticaje SDI na poljoprivredu težeći da utvrdi da li postoje mogućnosti za poboljšanja u poljoprivredi putem SDI. Rezultati istraživanja, prezentirani u radu, ukazuju da strane direktne investicije imaju značajan potencijal za podršku i unapređenje performansi poljoprivrede zemalja SEE. Međutim, da bi se iskoristili ovi potencijalni pozitivni efekti potrebni su veći obimi SDI kao i prepoznavanje ovih potencijalnih koristi od priliva SDI u poljoprivredu od strane vlada $i$ kreatora politika.
\end{abstract}

Ključne reči: strane direktne investicije, zemlje JIE, poljoprivreda.

5 Doc. dr Sandra Stojadinović Jovanović, Ekonomski fakultet, Univerzitet u Beogradu, Kamenička 6, 11000 Beograd, Srbija, Telefon: + 381113021 036, E-mail: sandra@ekof.bg.ac.rs

6 Doc. dr Boban Dašić, Fakultet za trgovinu i bankarstvo, Alfa Univerzitet, Palmira Toljatija 3, 11070 Beograd, Srbija, Telefon: + 381656265 211, E-mail: bobandasickg@gmail.com

EP 2015 (62) 3 (661-675) 